\title{
Efektivitas Terapi Antibiotika Demam Tifoid Pada Pediatrik Di Rumah Sakit X Kota Kediri
}

\author{
Feny Oktaviana ${ }^{*}$, Puput Noviana ${ }^{2}$ \\ ${ }^{1}$ Jurusan D4 Teknologi Laboratorium Medis, Fakultas Teknologi dan Manajemen Kesehatan, Institut \\ Ilmu Kesehatan Bhakti Wiyata Kediri \\ 2 Jurusan Farmasi, Fakultas Farmasi, Institut Ilmu Kesehatan Bhakti Wiyata Kediri \\ Jl. KH. Wahid Hasyim No. 65 Kota Kediri 64114, Indonesia \\ * Penulis Korespondensi. Email: feny.oktaviani@iik.ac.id
}

\section{ABSTRAK}

Demam tifoid memiliki insidensi tertinggi terjadi pada anak-anak. Terapi penyakit demam tifoid menggunakan antibiotik. Peningkatan resistensi bakteri terhadap antibiotik merupakan masalah global. Penelitian ini dilakukan untuk mengetahui adanya perbedaan efektivitas antibiotika pada terapi demam tifoid terhadap waktu bebas panas dan lama perawatan pasien pediatrik di ruang rawat inap rumah sakit X Kota Kediri. Penelitian ini merupakan analisis deskriptif melalui studi retrospektif rekam medik tahun 2017 dengan metode pengambilan data purposive sampling. Data diambil pada pasien anak penderita demam tifoid yang berusia 5-11 tahun di ruang rawat inap rumah sakit X Kota Kediri. Analisis statistika efektivitas terapi pada pasien pediatrik demam tifoid dilakukan menggunakan uji Kruskal-Wallis. Pasien anak yang dijadikan sampel pada penelitian ini sebanyak 38 orang. Antibiotik yang digunakan adalah ciprofloxacin sebesar 52,63\%, ceftriakson 28,95\%, cefuroxim 10,53\%, dan penicillin $7,89 \%$. Hasil analisis perbedaan efektivitas antibiotik terhadap waktu bebas panas diperoleh nilai sig > 0,05 $(0,947)$ dan terhadap lama perawatan didapatkan nilai sig $>0,05(0,329)$. Tidak ada perbedaan yang bermakna pada waktu bebas panas dan lama perawatan antara ceftriakson, cefuroxim, ciprofloxacin dan penicillin.

Kata Kunci:

Demam tifoid, waktu bebas panas, lama perawatan

$\begin{array}{ccc}\text { Diterima: } & \text { Disetujui: } & \text { Online: } \\ \text { 15-08-2021 } & \text { 26-08-2021 } & 30-08-2021\end{array}$

\section{ABSTRACT}

Typhoid fever has the highest incidence in children. Treatment for typhoid fever uses antibiotics. Increasing bacterial resistance to antibiotics is a global problem. This study was conducted to determine the differences in the effectiveness of antibiotics in the treatment of typhoid fever on the heat-free time and the length of treatment for pediatric patients in the inpatient ward of the X Hospital, Kediri City. This research is a descriptive analysis research. A retrospective study was conducted using medical records in 2017. Data were collected by purposive sampling. Data were taken on pediatric patients with typhoid fever aged 5-11 years. The statistical test used to analyze the effectiveness of therapy in pediatric patients with typhoid fever was performed using the Kruskal-Wallis test. The sample used in this study were 38 pediatric patients. The antibiotics used were ciprofloxacin $52.63 \%$, ceftriaxone $28.95 \%$, cefuroxim $10.53 \%$, and penicillin $7.89 \%$. The results of the analysis of differences in the effectiveness of antibiotics against heat-free time obtained a sig value $>0.05$ (0.947) and a sig value $>0.05$ (0.329) for the length of treatment. There was no significant difference in heatfree time and length of treatment between ceftriaxone, cefuroxim, ciprofloxacin and penicillin. Keywords: 


\begin{tabular}{ccc}
\hline Typhoid fever, heat-free time, length of treatment & \\
\hline Received: & Accepted: & Online: \\
$2021-08-15$ & $2021-08-26$ & $2021-08-30$ \\
\hline
\end{tabular}

\section{Pendahuluan}

Penyakit infeksi masih merupakan penyebab utama morbiditas dan mortalitas di dunia. Di samping itu penyakit infeksi juga bertanggung jawab pada penurunan kualitas hidup jutaan penduduk di berbagai negara maju dan berkembang. Menurut WHO sebanyak 25 juta kematian di seluruh dunia pada tahun 2011, sepertiganya disebabkan oleh penyakit infeksi[7]. Salah satu penyakit yang disebabkan oleh infeski adalah Typhus. Typhus (Demam tifoid, tifus abdominalis, enteric fever) disebabkan oleh infeksi mikroorganisme Salmonella enterica Subspesies enterica serotipe typhi (S. typhi) pada manusia[1]. Prinsip penularan penyakit demam tifoid adalah melalui fekal-oral[21]. Demam tifoid banyak ditemukan di negara berkembang dimana higiene pribadi dan sanitasi lingkungannya kurang baik. Prevalensi kasus bervariasi tergantung lokasi, kondisi lingkungan setempat, dan perilaku masyarakat[21].

Angka insidensi di seluruh dunia sekitar 17 juta per tahun dengan 600.000 orang meninggal karena penyakit ini. WHO memperkirakan 70\% kematian terjadi di Asia [21]. Di Indonesia terjadi peningkatan angka kejadian demam tifoid dengan kejadian sekitar 500 per 100.000 penduduk [6].Jumlah kejadian tertinggi demam tifoid terjadi pada pada anak-anak dengan usia 5-15 tahun, hal ini berdasarkan penelitian pada tahun 2008 bahwa jumlah kejadian demam tifoid sebesar 81,7 insidensi tiap 100.000 penduduk per tahun. Insidensi pada kelompok usia 0-1 tahun adalah sebesar 0 per 100.000 penduduk, insidensi pada 2-4 tahun sebesar 148,7 per 100.000 penduduk, pada usia 5-15 tahun sebesar 180,3 per 100.000 penduduk, dan usia $\geq 16$ tahun sebesar 51,2 per 100.000 [12].

Dokter dan ahli kesehatan masyarakat percaya bahwa demam tifoid masih merupakan salah satu dari lima penyakit demam paling umum penyebab kematian tertinggi di antara pasien di rumah sakit [1].

Ketepatan pemilihan antibiotik khususnya untuk anak-anak adalah hal yang perlu diperhatikan[15]. Terkendalinya pemilihan antibiotik dapat mencegah resistensi antimikroba dan menurunkan jumlah penggunaan antibiotik, sehingga dapat menurunkan biaya perawatan, mengurangi lama perawatan, meningkatkan penghematan rumah sakit serta meningkatkan kualitas pelayanan di rumah sakit[7]. Kloramfenikol merupakan pilihan terapi yang digunakan sejak akhir tahun 1980an. Selanjutnya, peningkatan resistensi antibiotik terhadap kloramfenikol, ampisilin, dan kotrimoksazol banyak dilaporkan. Ciprofloxacin merupakan antibiotik yang banyak disukai setelah munculnya strain MDR (multi drug resistance). Meskipun ciprofloxacin lebih unggul dibandingkan dengan sefalosporin, namun sefalosporin spektrum luas seperti ceftriaxone dan cefixime, serta azitromisin adalah alternatif yang cocok untuk $S$. thypi yang telah turun sensitifitasnya pada ciprofloxacin. Kombinasi sefalosporin dan azitromisin cukup sering digunakan untuk mengobati pasien yang gagal merespon terapi[20]. Antibiotik yang digunakan dalam mengobati demam tifoid sangat bervariasi saat ini, sehingga efektivitasnya perlu untuk diketahui. Parameter efektivitas terapi penggunaan antibiotika pada pediatrik yang terkena demam tifoid tanpa komplikasi adalah waktu bebas panas dan lama perawatan. Waktu bebas panas adalah penurunan suhu, bila suhu badan turun berarti pengobatannya berhasil, sedangkan bila suhu tetap 
tinggi mungkin ada infeksi lain, komplikasi, atau terjadi multidrug resistant Salmonella thypi (MDRST) [4]. Penelitian sebelumnya oleh Rampengan (2013) [13] melaporkan bahwa tidak ada perbedaan waktu bebas panas antara kloramfenikol, tiamfenikol, sefiksim dan azitromisin pada pengobatan demam tifoid, sehingga penelitian ini bertujuan untuk mengetahui apakah terdapat perbedaan efektivitas dari penggunaan antibiotik pada terapi demam tifoid terhadap waktu bebas panas dan lama perawatan pasien pediatrik di ruang rawat inap rumah sakit $X$ Kota Kediri. Luaran dari penelitian ini diharapkan dapat memberikan informasi dan evaluasi untuk pihak rumah sakit terkait pemilihan antibiotik untuk demam tifoid pada pasien pediatrik di rumah sakit X Kota Kediri.

\section{Metode}

Penelitian ini merupakan penelitian survei (survey research method) menggunakan rancangan analisis deksriptif secara retrospektif. Penelitian dilakukan di RS. X Kota Kediri pada bulan April-Mei 2018 dengan pengambilan data rekam medik pasien pada tahun 2017. Sampel dari penelitian ini adalah pasien anak usia 5-11 tahun [3] dengan diagnosis demam tifoid yang menjalani rawat inap dan mendapatkan terapi pengobatan antibiotika di RS. X Kota Kediri periode Januari-Desember 2017. Kriteria eksklusi dalam penelitian ini adalah pasien anak yang terdiagnosis demam tifoid dengan hasil catatan rekam medik dan pemeriksaan laboratorium yang tidak lengkap atau tidak dapat dikonfirmasi sebagai penunjang utama penegakan diagnosis dokter terhadap demam tifoid; pasien anak yang terdiagnosis demam tifoid dengan komplikasi infeksi lain; dan pasien anak pulang paksa.

Variabel bebas pada penelitian ini adalah penggunaan antibiotik, sedangkan variabel terikat berupa waktu bebas panas dan lama perawatan di rumah sakit. Analisis data perbandingan waktu bebas panas dan lama perawatan pada tiap kelompok antibiotik dianalisis dengan menggunakan uji Kruskal-Wallis menggunakan program SPSS. Indikator adanya perbedaan yang bermakna apabila nilai Chi-square (statistika hitung) $>$ statistika tabel dan nilai sig $<0,05$.

\section{Hasil dan Pembahasan}

Subjek penelitian yang memenuhi kriteria inklusi dan eksklusi pada penelitian ini adalah sebanyak 38 pasien pediatrik. Distribusi pasien berdasarkan jenis kelamin dapat dilihat pada Gambar 1. Presentasi pasien laki-laki adalah sebanyak 22 (57,90\%) dan presentasi pasien perempuan sebanyak $16(42,10 \%)$. Berdasarkan penelitian sebelumnya oleh Hasanah (2012), demam tifoid dapat menyerang siapa saja baik laki-laki atau perempuan, sehingga jenis kelamin tidak memiliki hubungan yang bermakna dengan kejadian demam tifoid. 


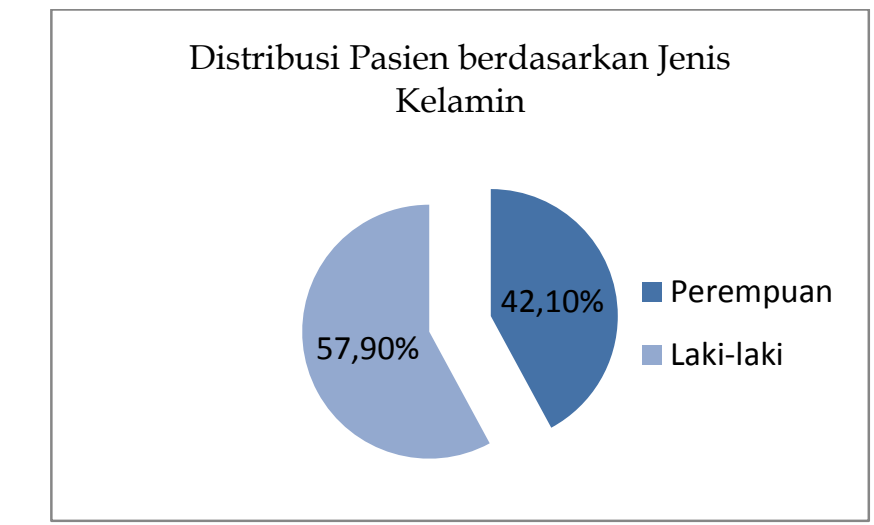

Gambar 1. Distribusi pasien berdasarkan jenis kelamin

Usia yang paling banyak terserang demam tifoid pada penelitian ini adalah pasien anak yang berusia 6 tahun dengan presentase 26,31\%. Usia >5 - 12 tahun anak-anak cenderung memiliki aktivitas fisik yang banyak atau dapat dikatakan sibuk dengan pekerjaan, sehingga kurang memperhatikan pola makannya. Hal ini menyebabkan anak cenderung lebih memilih makan di luar rumah atau jajan di tempat lain, khususnya pada anak usia sekolah, yang mungkin tingkat kebersihannya masih kurang dimana bakteri Salmonella thypi banyak berkembang biak khususnya dalam makanan sehingga mereka tertular demam tifoid. Pada usia anak sekolah, mereka cenderung kurang memperhatikan kebersihan atau hygiene perseorangannya yang mungkin diakibatkan karena ketidaktahuannya bahwa dengan jajan makanan sembarang dapat menyebabkan tertular penyakit demam tifoid. Di daerah endemik, anak-anak usia sekolah berada pada resiko tertinggi perkembangan infeksi $S$. Typhi karena berkurangnya antibodi pasif yang diperoleh dari ibu [11]. Aktivitas yang banyak juga dapat menyebabkan sel yang ada ditubuh mengalami stres. Pada sel yang stress maka penampilan kelelehan dapat berupa nekrosis dan apoptosis. Adanya nekrosis dan apoptosis dialami oleh sel maka kekebalan tubuh akan menurun dan kerentanan individu terahadap infeksi meningkat [5].

Berdasarkan Gambar 2 dapat diketahui bahwa terapi yang paling banyak digunakan pada pasien pediatrik adalah antibiotika (100\%). Penggunaan antibiotika dimaksudkan untuk membunuh atau menghambat pertumbuhan bakteri Salmonella thypi[18]. Selain antibiotika, terapi lain yang digunakan di RS X Kediri terdiri dari elektrolit (100\%), obat saluran pencernaan $(97,37 \%)$, analgesik $(81,58 \%)$, antipiretik $(44,74 \%)$, obat saluran pernafasan $(65,79 \%)$, suplemen $(42,10 \%)$ dan kortikosteroid $(28,95 \%)$. Pemberian obatobat tersebut bertujuan untuk mengurangi dan mengatasi gejala serta keluhan-keluhan yang dirasakan, mencegah komplikasi, dan menghindari kematian [9]. 


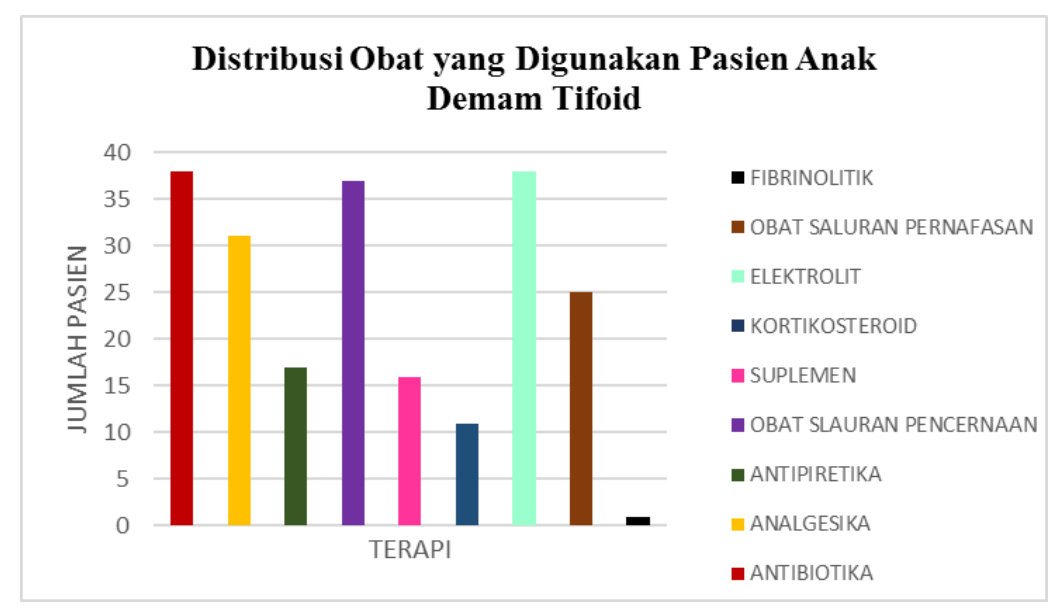

Gambar 2. Distribusi obat yang digunakan pasien pediatrik demam tifoid

Penggunaan antibiotik bertujuan untuk menghambat dan membunuh mikroorganisme atau bakteri penyebab infeksi pada demam tifoid. Penatalaksanaan terapi demam tifoid menggunakan antibiotik sudah sesuai untuk mengeradikasi Salmonella typhii, bakteri penyebab demam tifoid. Salmonella typhi merupakan bakteri gram negatif yang bersifat anaerob dan merupakan patogen penting bagi manusia karena habitatnya di saluran usus manusia ${ }^{[2]}$. Berdasarkan diagram pada Gambar 3, dapat diketahui bahwa jenis antibiotik yang banyak digunakan adalah golongan flourquinolone, yaitu ciprofloxacin dengan bentuk sediaan injeksi sebesar 52,63\%. Antibiotik lain yang digunakan adalah ceftriaxon $28,95 \%$, cefuroxim $10,53 \%$, dan penisilin $7,89 \%$.

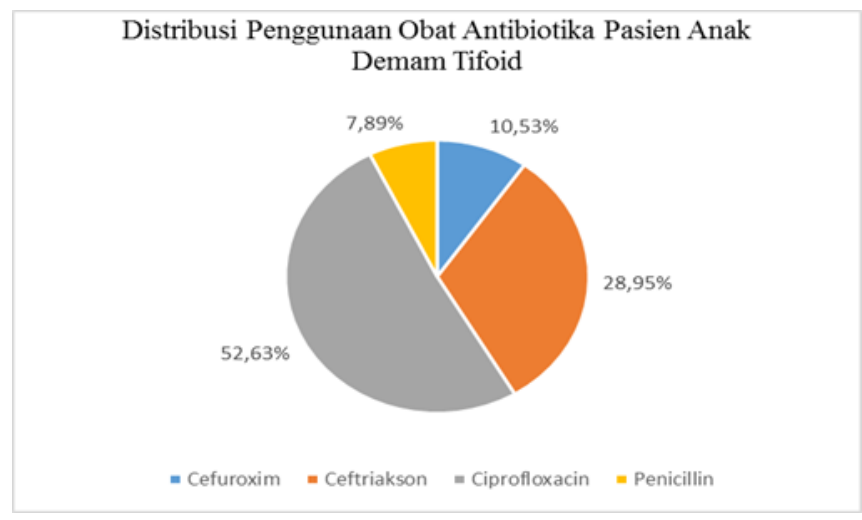

Gambar 3. Distribusi penggunaan antibiotika pasien pediatrik di RS X Kota Kediri

Pola penggunaan antibiotik untuk demam tifoid pada pasien pediatrik di RS X Kota Kediri antara lain adalah penicilin, ciprofloxacin, cefuroxim, dan ceftriakson. Pola penggunaan antibiotik tersebut sesuai dengan salah satu penelitian dari Sidabutar dan Satari (2010) [16] yang melaporkan bahwa kloramfenikol sudah tidak digunakan lagi sebagai terapi lini pertama pada beberapa daerah endemik demam tifoid, tetapi sudah menggunakan antibiotik sefalosporin generasi ketiga, diantaranya cefixime dan ceftriaxone. Terapi kloramfenikol pada pasien anak dapat menyebabkan aplasia sumsum tulang belakang. Ciprofloxacin dan ceftriakson terbukti efektif melawan infeksi bakteri Salmonella typhi yang telah resisten multi drug resistance (MDR) terhadap 
antibiotika kloramfenikol [19]. Sefalosporin generasi ketiga mempunyai efikasi dan toleransi yang baik untuk pengobatan demam tifoid. Sefalosporin generasi ketiga yang digunakan dalam pengobatan disini meliputi ceftriaxone. Ceftriakson adalah antibiotik yang digunakan untuk mengobati demam tifoid yang resisten terhadap fluoroquinolon seperti ciprofloxacin [13].

Respon terapi pada penelitian ini dilihat dari waktu bebas panas dan lama perawatan. Rata-rata waktu bebas panas pada penelitian ini berkisar antara 1,6 - 2 hari dan rata-rata lama perawatan berkisar antara 3,5 - 4,6 hari. Antibiotik yang memberikan rata-rata waktu bebas panas paling cepat adalah penicillin, sedangkan antibiotik dengan rata-rata lama perawatan yang paling singkat adalah ceftriaxone. Setelah diuji menggunakan uji Kruskal-Wallis diperoleh hasil bahwa tidak ada perbedaan bermakna pada waktu bebas panas antara ceftriakson, cefuroxim, ciprofloxacin dan penicillin nilai sig $(0,947>0,05)$. Hasil penelitian ini sama dengan penelitian Rampengan (2013) [13], bahwa tidak ada perbedaan waktu bebas panas antara kloramfenikol, tiamfenikol, sefiksim dan azitromisin pada pengobatan demam tifoid. Hal ini berbeda dengan hasil penelitian Sidabutar dan Satari (2010) [16]. yang menunujukkan bahwa terdapat perbedaan waktu bebas panas pada terapi antibiotika antara ceftriakson dan kloramfenikol. Waktu bebas panas yang cepat akan mempersingkat terapi, efek samping lebih ringan, angka kekambuhan yang lebih rendah, dan waktu perawatan yang singkat. Dasar pengambilan keputusan lama perawatan antibiotik pada pasien pediatrik diperoleh dari nilai sig $(0,329>0,05)$, maka keputusan hipotesis adalah tidak ada perbedaan bermakna pada lama rawat inap antara ceftriakson, cefuroxim, ciprofloxacin dan penicillin.

Pemberian ceftriakson dalam pengobatan demam tifoid di rumah sakit lebih dianjurkan dibandingkan kloramfenikol, sebab ceftriakson lebih cepat menunjukkan waktu bebas panas sehingga lama terapi lebih singkat, efek samping lebih ringan dan angka kekambuhan yang lebih rendah dibandingkan kloramfenikol [16]. Ceftriakson digunakan sebagai alternatif apabila bakteri sudah resisten terhadap antibiotik lainnya, seperti amoksisilin, kloramfenikol, sefotaksim dan ampisillin. Ciprofloxacin merupakan antibiotik yang banyak digunakan pada pasien pediatrik demam tifoid di rawat inap RS $X$ Kota Kediri. Ceftriakson dan cefotaxim merupakan antibiotik golongan sefalosporin generasi ketiga yang memiliki spektrum kerja yang sangat luas dan sangat efektif terhadap bakteri Gram negatif. Namun, harga ceftriakson lebih mahal dibandingkan cefotaksim, sehingga hal ini yang mungkin menjadi salah satu penyebab jarang digunakannya ceftriakson pada pengobatan demam tifoid di RS X Kediri. Berdasarkan penelitian Nurjannah dkk (2012) [10] mengenai faktor yang berhubungan dengan lama hari rawat pasien demam tifoid di ruang rawat inap RSUD Pangkep menyatakan diet dengan dukungan gizi dan pemberian vitamin serta mineral diperlukan untuk mendukung keadaan pasien sehingga dapat mempersingkat lamanya perawatan.

\section{Kesimpulan}

Golongan antibiotika yang banyak digunakan adalah golongan fluoroquinolone yaitu ciprofloxacin. Rute pemakaian yang digunakan pasien pediatrik demam tifoid adalah intravena dengan bentuk sediaan injeksi. Analisis statistika efektivitas terapi antibiotika pasien anak demam tifoid menggunakan uji Kruskal-Wallis menunjukkan bahwa tidak ada perbedaan bermakna pada waktu bebas panas dan lama rawat inap antara ceftriakson, cefuroxim, ciprofloxacin dan penicillin. 


\section{Referensi}

[1] Ali, S. 2006. Aspects of environment, host and pathogen interaction. Typhoid fever. Royal Dutch Academy of Sciences project no. 99-MED-02. Jakarta: Atma Jaya Catholic University of Indonesia

[2] Andino and Hanning. 2015. Review Article : Salmonella enterica : Survival, Colonization, and Virulence Differences among Serovars. Hindawi Publishing Corporation. Scientific World Journal. pp.1-16

[3] Depkes, R.I., 2009, Klasifikasi Umur Menurut Kategori, Jakarta : Ditjen Yankes

[4] Fithria, R.F., Kiki D., and Risma P.F., 2015, Perbedaan Efektivitas Antibiotik Pada Terapi Demam Tifoid Di Puskesmas Bancak Kabupaten Semarang Tahun 2014, Prosiding Seminar Nasional Peluang Herbal Sebagai Alternatif Medicine 2015, Fakultas Farmasi Universitas Wahid Hasyim, Semarang

[5] Jawetz, Melnick, Adelberg. 2008. Mikrobiologi Kedokteran. (H. Hartanto, C. Rachman, A. Dimanti, A. Diani). Jakarta : EGC.p.199 - 200 : 233

[6] Juwita, S., Edi, H., Budiarti, L.Y., 13, Pola Sensitivitas In Vitro Salmonella typhi Terhadap Antibiotika Kloramfenikol, Amoksisilin, dan Kotrimoksazol, Di Bagian Anak Rsud Ulin Banjarmasin Periode Mei-September 2012, Berkala Kedokteran, pp. 21-29.

[7] Kemenkes RI, 2011, Pedoman Pelayanan Kefarmasian Untuk Terapi Antibiotik, Kementerian Kesehatan Republik Indonesia, Jakarta, pp. 27, 37.

[8] Lestari, W., Almahdi, A., Zubir, N., Darwin, D., 2011, Studi Penggunaan Antibiotik Berdasarkan Sistem ATC/DDD dan Kriteria Gyysens di Bangsal Penyakit Dalam RSUP DR.M.Djamil Padang, Laporan Penelitian, Fakultas Farmasi Pascasarjana Universitas Andalas, Padang

[9] Nelwan, RHH., 2012, Tata Laksana Terkini Demam Tifoid, Continuing Medical Education, Divisi Penyakit Tropik dan Infeksi Departemen Ilmu Penyakit Dalam, FKUI/RSCM-Jakarta, CDK-192/vol. 39 no.4, pp. 247-250.

[10] Nurjannah H.R., H. A. Alam \& Y. Haskas. 2012. Faktor yang berhubungan dengan lama hari rawat pasien demam tifoid di ruang rawat inap RSUD Pangkep. ISSN 1(5): 1-7.

[11] Nuraini, F. A., Garna Herry, Respati Titik, 2015, Perbandingan Kloramfenikol dengan Seftriakson terhadap lama hari turun demam pada anak demam tifoid, Skripsi, Fakultas Kedokteran Universitas Islam Bandung, Bandung

[12] Ochiai RL, Acosta CJ, Danovaro-Holliday MC, Baiqing D, Bhattacharya SK, Agtini MD, Bhutta ZA, Canh DG, Ali M, Shin S, Wain J, Page AL, Albert MJ, Farrar J, AbuElyazeed R, Pang T, Galindo CM, von Seidlein L, Clemens JD; Domi Typhoid Study Group. A study of typhoid fever in five Asian countries: disease burden and implications for controls. Bull World Health Organ. 2008 Apr;86(4):260-8. doi: 10.2471/blt.06.039818. Erratum in: Bull World Health Organ. 2015 Apr 1;93(4):284. Erratum in: Bull World Health Organ. 2015 Jun 1;93(6):440. PMID: 18438514; PMCID: PMC2647431.

[13] Rampengan N.H., 2013, Antibiotik Terapi Demam Tifoid Tanpa Komplikasi pada Anak, Sari Pediatri, Vol. 14, No. 5, halaman 271-272.

[14] Riyatno, I.P., dan Sutrisna, E., 2011, Cost-Effectiveness Analysis Pengobatan Demam Tifoid Anak Menggunakan Sefotaxime dan Kloramfenikol di RSUD. Prof. Dr. Margono Soekarjo Purwokerto, Mandala of Health. Volume 5, Nomor 2., pp. 1-5. 
[15] Roespandi, H., dan Nurhamzah, W., 2007, Buku Saku Pelayanan Kesehatan Anak di Rumah Sakit, Departemen Kesehatan Republik Indonesia, Jakarta, hal. 167-168

[16] Sidabutar, S., Hindra Irawan Satari. 2010. Pilihan Terapi Empiris Demam Tifoid pada Anak: Kloramfenikol atau Seftriakson?. Departemen Ilmu Kesehatan Anak, RS Dr Cipto Mangunkusumo, Fakultas Kedokteran Universitas Indonesia, Jakarta . Sari Pediatri 2010;11(6):434-9

[17] Soendro, Triono. 2008. Riset Kesehatan Dasar (RISKESDAS) 2007. Laporan Nasional 2007. Badan Penelitian dan Pengembangan Kesehatan Departemen Kesehatan Republik Indonesia. Jakarta : Kementerian Kesehatan Republik Indonesia

[18] Tjay, T.H. and Rahardja, K., 2015, Obat-Obat Penting: Khasiat, Penggunaan, dan Efekefek Sampingnya, 7th Edition, Gramedia, Jakarta, pp. 296-297.

[19] Upadhyay, Rajesh, Milind Y Nadkar, A Muruganathan., et al. 2015. API Recommendation for the Management of Typhoid Fever. Journal of The Association of India,pp. 77-96

[20] Veeraraghavan B, Pragasam AK, Bakthavatchalam YD, Ralph R. Typhoid fever: issues in laboratory detection, treatment options \& concerns in management in developing countries. Future Sci OA. 2018;4(6):FSO312. Published 2018 Jun 26. doi:10.4155/ fsoa-2018-0003

[21] Widoyono, 2011, PENYAKIT TROPIS: Epidemiologi, Penularan, Pencegahan, dan Pemberantasannya, Edisi Kedua, Penerbit Erlangga, Jakarta, pp. 4445. 